\title{
Analysis Service on Student Satisfaction with Motivation as Moderating Variable
}

\author{
Alana Damaris ${ }^{1}$, Ngadino Surip $^{2}$, Antonius Setyadi ${ }^{3}$
}

\begin{abstract}
:
Purpose: The main aim of this study is to examine the influence of service quality (HEdPERF Model) on student satisfaction with motivation as moderating variable.

Design/Methodology/Approach: The sample consists of 210 non-traditional students from the post graduate program of Mercu Buana University Jakarta, from 6 Master's degree programs. The technique of data analysis used to test the hypotheses models were Structural Equation Model (SEM) with Linear Structural Model (LISREL) version 8.80.

Findings: The result of all hypotheses testing showed the empirical data to be fitted quite well. The structural relationship between the variables may be summarized as follows: (1) There is a positive and significant influence of academic aspect on student satisfaction with motivation as moderating variable; (2) There is no influence of non-academic aspect on student satisfaction with motivation as moderating variable; (3) There is a positive and significant influence of access on student satisfaction with motivation as moderating variable; (4) There is a positive and significant influence of program issue on student satisfaction with motivation as moderating variable; (5) There is no influence of reputation on student satisfaction with motivation as moderating variable.

Practical implications: Since the academic aspect, non-academic aspect, access, program issue, reputation and motivation simultaneously influence student satisfaction the results of the study can be used accordingly.

Originality/Value: The article proposed certain issues for the universities to improve programs such as quality, variability, structure, delivery of teaching and flexibility of time.
\end{abstract}

Keywords: Service quality, HEdPERF model, motivation, student satisfaction.

JEL code: 123.

Paper type: Research article.

\footnotetext{
${ }^{1}$ Universitas Mercu Buana, Jakarta

${ }^{2}$ Universitas Mercu Buana, Jakarta

${ }^{3}$ Corresponding author, Universitas Mercu Buana, Jakarta, e-mail: setyadi@mercubuana.ac.id
} 


\section{Introduction}

The education sector is undergoing rapid growth nowadays. A person's awareness to pursue an academic education is increasing, not only for parents who have a desire for their children to go to higher education, but even older people have a desire to pursue higher education. Similarly, this is happening at the University of Mercu Buana, where in recent years they have experienced a very rapid growth in the enrollment of adult learners. A university is not just an institution for advanced learning, but also a business. The huge amount of money has been issued to a lot of universities to improve the image and improve their position and ranking (Azoury et al. 2014). Therefore, the university can succeed if their customers get an offer of something they want to learn and, on the standards, they feel is acceptable (Brown and Mazzarol, 2009). Students are key customers, and therefore they have an important role in evaluating service quality in the college industry (Subrahmanyam and Raja, 2012). In the context of college, the student is considered its main customer (Hill, 1995). Students have become the focus of universities in the context of developing a college marketing strategy (Orîndaru, 2015).

One of the segment markets targeted by universities are the non-traditional students. This non-traditional term refers to students over 25 (twenty-five) years old, who return to college for an academic degree, or an advanced academic degree. According to Horn (1996), non-traditional students are those who have "delayed enrollment into post-secondary education, attend part-time, are financially independent, work full time while enrolled, had dependents other than a spouse, was a single parent, or did not obtain a standard high-school diploma." These nontraditional students in general have unique challenges in trying to complete their studies, including financial challenges, as they have responsibilities in their lives, such as full-time employment, family responsibilities and parenthood, to share the attention between work, family, and college. Looking at reports of increasing numbers of non-traditional students worldwide, especially in the United States, researchers also see the same thing happening at Mercu Buana University. The classes provided in Regular 2 (two) and 3 (three) programs, with classes held over the weekend, and on weekday evenings, have increased rapidly in recent years. This number reaches $50 \%$ of the total students who are members of the University of Mercu Buana (Directorate of Student Affairs UMB).

Thus, it is important for a university to attract new students, through the marketing aspect. And it is very important in this aspect of marketing to see the aspect of satisfaction from students. In a competitive marketplace, where organizations seek customers, satisfaction becomes an important factor in the marketing strategy. By measuring customer satisfaction, the organization can get an indication of how well an organization is is doing. Researchers recognize that customers have expectations, and this is the standard for evaluating the service performance of a company (Jalasi, 2014). However, the survey conducted on student satisfaction got negative responses in some respects, so this research is intended to analyze the perception about the 
quality of University's service to student's satisfaction. Given that the sample of this study is non-traditional students, this study will also see how the motivation of these non-traditional students interact with perceptions about the quality of these services so that it influences student satisfaction.

\section{Literature Review}

\subsection{Student Satisfaction}

Student satisfaction is a good subjective evaluation of students of various outcomes and experiences associated with education (Elliot and Shin, 2002). Wu et al. (2010) define satisfaction as the sum of a student's behavioral beliefs and attitudes that result from aggregating all the benefits that a student receives from using the blended system. This satisfaction is an affective aspect of students covering three aspects: (1) The customer service model, which is the affective aspect as the result of the interaction between the lecturer and the administrative staff with the student; (2) the Happy-productive model, which is the affective aspect of the student resulting from feeling satisfied, being productive and loyal; and (3) the investment model, which is the effort they devote to college is as valuable as an investor looking at their money in terms of seeing their reward from what they have already spent (Carter, 2014).

\subsection{Motivation}

Motivation is an internal driver needed to direct one's actions and behaviors to achieve a goal. Motivation is an internal condition and is sometimes described as need and desire. Many psychologists use the term motivation to describe a process that moves human behavior and gives direction or purpose to a behavior (Galbraith, 1990). There are two dimensions of motivation, namely (a) intrinsic motivation meaning the primary motivation to learn is an internal driver, such as the desire to learn and gain knowledge; and (b) extrinsic motivation - meaning that learning motivation is derived from external factors and to obtain external results (Ryan and Deci, 2000).

\subsection{Quality of Services in Higher Education}

Abdullah Firdaus (2004) proposed a HEdPERF (Higher Education Performance) model, a new and more comprehensive measurement scale for university performance, which tries to capture the authentic determinations of service quality in the higher education sector. This model establishes the specific factors for measuring the quality of services because the student is the primary customer in the service. Customer orientation is an important factor considered in maintaining the quality of services. The five aspects reviewed by this model are academic aspects, nonacademic aspects, access, program issues, as well as the University's reputation. 


\subsubsection{Academic Aspects}

The academic aspect is a factor consisting of things that describe factors that are the responsibility of academic staff or teaching staff. These factors represent academic responsibility and underscore key attributes, such as, positive attitudes, good communication skills, permitting reasonable consultation, and being able to provide constructive advice and input to students.

\subsubsection{Non-academic aspect}

The non-academic aspect relates to the responsibilities of non-academic staff, which is the ability and willingness of the administrative staff to show respect, provide fair treatment, and secure the confidentiality of information. This dimension also illustrates the importance of ease of approach, positive attitude and good communication skills, and providing services in a good time frame.

\subsubsection{Access}

This factor consists of items that relate to the perceived ease of students to approach, ease of contact, availability, and convenience, in lectures both to lecturers and administrative staff.

\subsubsection{Program issues}

This factor emphasizes the importance of offering the structured programs that support lectures. This includes program flexibility, programs with a wide range of subjects, specialization and quality of programs offered.

\subsubsection{Reputation}

A company's reputation is generally defined as the collective valuation of the observer based on an assessment of the financial, social, and environmental impacts attributed to the company. Gaining a positive reputation is important to a business while reputation represents an intangible asset (Vidaver-Cohen, 2007). Reputation is an important issue for the university in terms of projecting its professional image. It includes the university's ability to offer prestigious and broad-based programs with flexible structures, recognized degrees locally and internationally, and has a highly educated and experienced faculty. The university's reputation is one of the determinants of satisfaction (Gibson, 2010).

Hence, this study hypothesizes that the five dimensions of HEdPERF Model significantly influence student satisfaction with motivation as a moderating variable:

H1: The academic aspect has a positive and significant influence on student satisfaction moderated by motivation.

H2: The non-academic aspect has a positive and significant effect on student satisfaction moderated by motivation.

H3: Access has a positive and significant influence on student satisfaction moderated by motivation. 
H4: Program Issues have a positive and significant influence on student satisfaction moderated by motivation.

H5: Reputation has a positive and significant influence on student satisfaction moderated by motivation.

Figure 1. Conceptual Framework

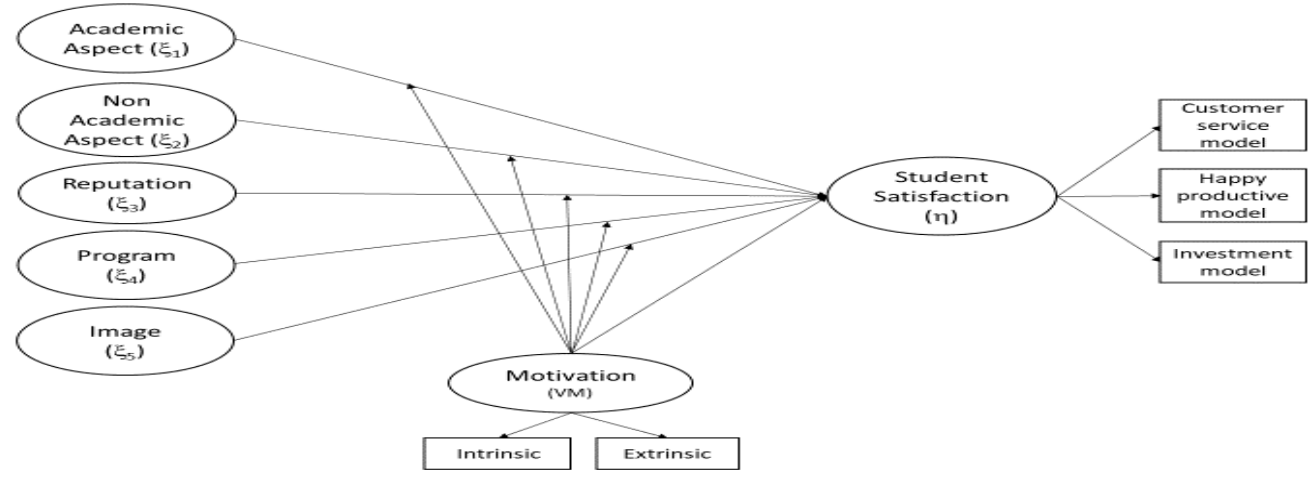

\section{Methodology}

The population for this study was limited to non-traditional students of postgraduate programs at Mercu Buana University, which numbers are shown in Table 1 below. The sample size consisted of 210 students.

Table 1. Total of Mercu Buana University Post-Graduate Students 2016/2017

\begin{tabular}{|c|c|c|c|c|c|c|}
\hline \multirow[b]{2}{*}{ No } & \multirow[b]{2}{*}{ Programs } & \multicolumn{3}{|l|}{ Status } & \multirow[b]{2}{*}{ Total } & \multirow[b]{2}{*}{$\%$} \\
\hline & & Active & $\begin{array}{l}\text { Non- } \\
\text { Active }\end{array}$ & $\begin{array}{l}\text { On } \\
\text { Leave }\end{array}$ & & \\
\hline 1 & Master's in Management & 1.912 & 274 & 24 & 2.210 & $58,17 \%$ \\
\hline 2 & $\begin{array}{l}\text { Master of Science in } \\
\text { Communication }\end{array}$ & 442 & 75 & 4 & 521 & $13.72 \%$ \\
\hline 3 & $\begin{array}{l}\text { Master of } \\
\text { Engineering }\end{array}$ & 217 & 23 & 1 & 241 & $6.35 \%$ \\
\hline 4 & $\begin{array}{l}\text { Master's in electrical } \\
\text { engineering }\end{array}$ & 166 & 8 & - & 174 & $4.58 \%$ \\
\hline 5 & Master of Accounting & 499 & 1 & 62 & 562 & $14.79 \%$ \\
\hline 6 & Master's in civil engineering & 88 & 3 & - & 91 & $2.39 \%$ \\
\hline & TOTAL & 3.324 & 384 & 91 & 3.799 & $100 \%$ \\
\hline
\end{tabular}

Source: Researcher analysis output (2017).

\subsection{Research Instrument}

The constructs in this study were measured using a five-point Likert-type scale. For all measurement item across all categories, scores ranged from 1 (strongly disagree) to 5 (strongly agree). Academic aspects and non-academic aspects were assessed using nine items; access using three items; programs issue using four items, and 
reputation using five items; all these were adapted from Abdullah (2006a) and Ali et al. (2014). For instrument assessment, Cronbach's alpha was calculated for each scale, in a pilot study distributed to 30 (thirty) participants. All scales were found reliable reaching the minimum threshold of 0.70 value, as shown in Table 2 below:

Table 2. Reliability of research instrument

\begin{tabular}{lll}
\hline Construct & No. of items & Cronbach's alpha \\
\hline Academic aspects & 9 & 0.884 \\
Non-academic aspects & 9 & 0.776 \\
Access & 3 & 0.834 \\
Program Issue & 4 & 0.872 \\
Reputation & 5 & 0.778 \\
Motivation & 5 & 0.639 \\
Student Satisfaction & 6 & 0.874 \\
\hline
\end{tabular}

Source: Researcher analysis output (2017).

The hypotheses in this study were tested based on structural equation modeling using the linear structural relations method 8.80.

\section{Results}

\subsection{Measurement model}

The measurement model for convergent validity was done first. This method was used to measure the factor loading, composite reliability (CR) and average variance extracted (AVE) (Hair et al., 2006). Table 3 shows that factor loading of all items exceeded the cut off value of 0.5 . CR values exceeded the recommended value of 0.7 , and AVE of 0.4 .

Table 3. Data Validity and Reliability

\begin{tabular}{|c|c|c|c|c|c|}
\hline Construct & Item & Pernyataan & Loading & CR & AVE \\
\hline \multirow[t]{6}{*}{$\begin{array}{l}\text { Student } \\
\text { Satisfaction }\end{array}$} & KPM1 & $\begin{array}{l}\text { I am satisfied with the interaction with UMB } \\
\text { lecturers. }\end{array}$ & 0.69 & \multirow{6}{*}{0.913} & \multirow{6}{*}{0.638} \\
\hline & KPM2 & $\begin{array}{l}\text { I am satisfied with the interaction with staff at } \\
\text { the College Administration Bureau. }\end{array}$ & 0.72 & & \\
\hline & KРM3 & $\begin{array}{l}\text { I am satisfied with my lectures, so I do the tasks } \\
\text { with enthusiasm }\end{array}$ & 0.86 & & \\
\hline & KPM4 & $\begin{array}{l}\text { I feel satisfied lecturing at UMB, so I will boast } \\
\text { UMB in front of my relationship. }\end{array}$ & 0.79 & & \\
\hline & KPM5 & $\begin{array}{l}\text { I feel satisfied because the quality of teaching in } \\
\text { accordance with the cost that I spend. }\end{array}$ & 0.84 & & \\
\hline & KPM6 & $\begin{array}{l}\text { I feel satisfied because I feel the time, I use to } \\
\text { study at UMB is not in vain. }\end{array}$ & 0.88 & & \\
\hline \multirow[t]{3}{*}{ Motivation } & MTV1 & $\begin{array}{l}\text { I went back to college to fulfill my desire to } \\
\text { learn. }\end{array}$ & 0.76 & \multirow{3}{*}{0.765} & \multirow{3}{*}{0.402} \\
\hline & MTV2 & $\begin{array}{l}\text { I went back to college because I wanted to } \\
\text { expand networking. }\end{array}$ & 0.65 & & \\
\hline & MTV3 & $\begin{array}{l}\text { I want to get a higher academic degree with } \\
\text { reentering college now to be more appreciated in }\end{array}$ & 0.65 & & \\
\hline
\end{tabular}




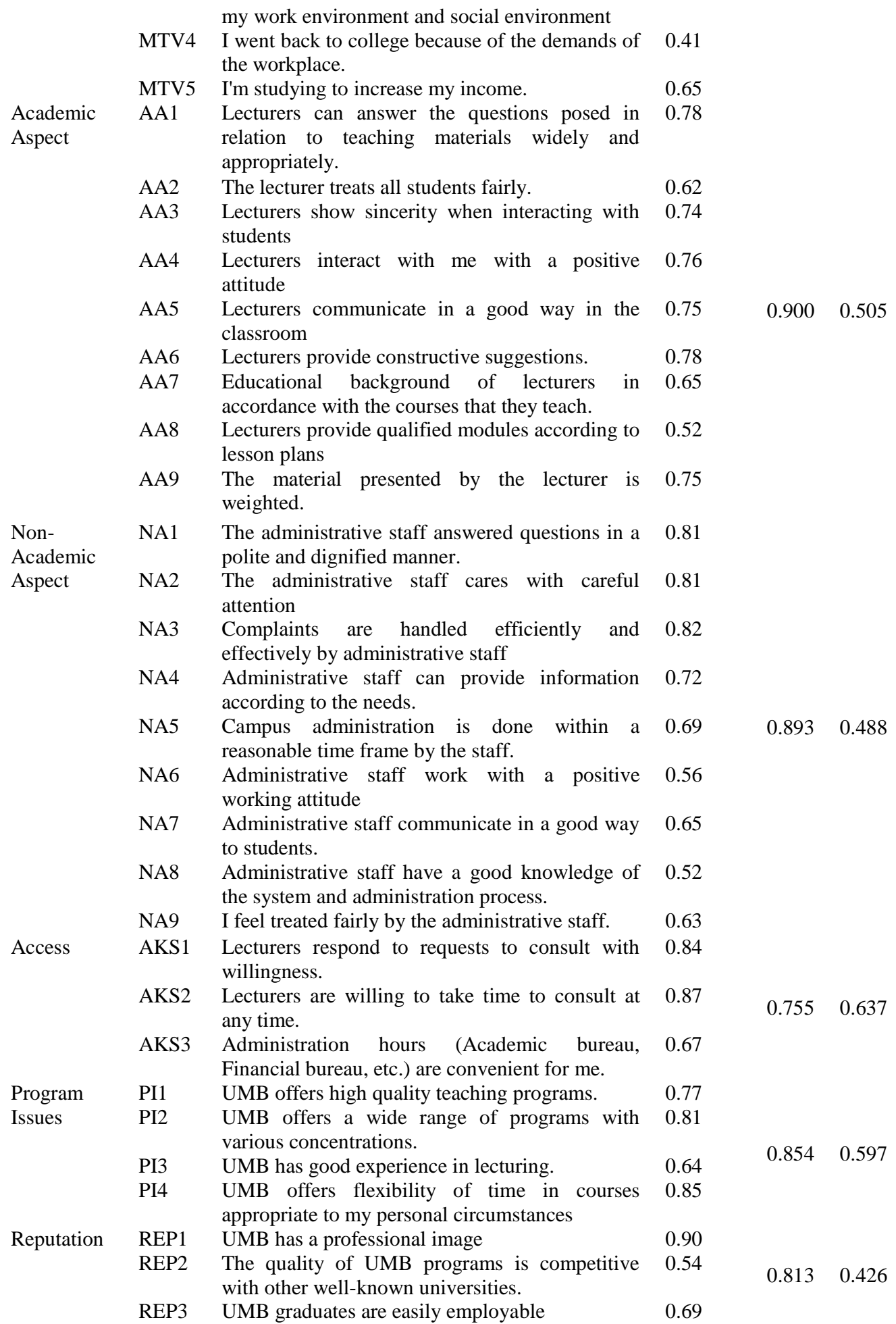


REP4 UMB has a good reputation in the community 0.73

REP5 The campus has good recreational facilities. 0.51

After doing the calculation and analysis of Confirmatory Factor Analysis (CFA), the next step was measuring SEM analysis including the assumption of normality test and fitness test on the whole model. Testing the normality of data relates to the size of skewness and kurtosis. Skewness indicates the degree of asymmetry of a distribution around the mean. Skewness and/or kurtosis show normally distributed data when the p-value exceeds 5\% (0.05). After normality analysis, all indicators show a p-value above 0.05 , which means all data is normally distributed. Thus, the goodness of Fit index of the model was conducted, with the result as shown in the Table 4 below:

Table 4. Goodness of Fit Structural Equation Model (SEM)

\begin{tabular}{lll}
\hline GOF Measurement & Value & Goodness of Fit \\
\hline Goodness of Fit Index (GFI) & 0.85 & Marginal Fit \\
Standardized Root Mean Square Residual (SRMR) & 0.079 & Good Fit \\
Root Mean Square Error of Approximation (RMSEA) & 0.067 & Good Fit \\
Non-Normed Fit Index (NNFI) & 0.97 & Good Fit \\
Normed Fit Index (NFI) & 0.94 & Good Fit \\
Relative Fit Index (RFI) & 0.93 & Good Fit \\
Incremental Fit Index (IFI) & 0.97 & Good Fit \\
Comparative Fit Index (CFI) & 0.97 & Good Fit \\
\hline
\end{tabular}

Based on the above table, it can be noted that the value of GFI is 0.85 . GFI is said to be marginally fit (still acceptable) if the value is less than 0.90. The SRMR value is 0.079 , this value exceeds the 0.05 threshold but is still below 0.08 , so this was included in the category of marginal fit (still acceptable). Consequently NNFI, NFI, IFI, and CFI all have values $\geq 0.90$, which means that everything can be categorized as a good fit. Thus, it can be concluded that the overall model of the hybrid measured indicates a good fit.

\subsection{Causal Relationship Analysis}

The analysis of causal relationships on the structural model is divided into two. The first model is a hypothesis of direct exogenous overall influence (academic aspects, non-academic aspects, access, program issues, reputation and motivation) to endogenous variables (student satisfaction), while the second model is a moderation test (Motivation as the moderating variable). The statistical test for the causal relation of the structural model is carried out with a significance level of 5\% so that the critical value of $t$-value is \pm 1.96 . This analysis yielded the following structural equations:

$\mathrm{KPM}=0.22 * \mathrm{AA}+0.23 * \mathrm{NA}+0.19 * \mathrm{AKS}+0.23 * \mathrm{PI}-0.11 * \mathrm{REP}+0.29 * \mathrm{MTV}$, Error var. $=0.32, \mathrm{R}^{2}=$ 0.68

$$
\begin{array}{lccccc}
(0.090) & (0.086) & (0.086) & (0.11) & (0.11) & (0.075) \\
2.43 & 2.64 & 2.19 & 2.03 & -1.01 & 3.83
\end{array}
$$

$\begin{array}{llllll}2.43 & 2.64 & 2.19 & 2.03 & -1.01 & 3.83\end{array}$


From the structural form equation above, we can see the value of $R^{2} . R^{2}$ value intends to show how much each of the exogenous variables can explain the endogenous variables. The variable KPM (Student Satisfaction) has an $\mathrm{R}^{2}$ value of 0.68. This figure indicates that academic aspect, non-academic aspect, Access, Program Issues, Reputation and Motivation simultaneously influence 68\% of Student Satisfaction, while the rest is explained by other factors outside this research.

In this study, hypothesis analysis begins with the calculation of the direct influence of exogenous variables on endogenous variables. The test for this analysis is done with a significance level of $5 \%$, resulting in a critical t-value of \pm 1.96 . The direct effect is obtained when the $t$-value is $\geq 1.96$, while the exogenous variable is considered to have no direct effect if the t-value is $<1.96$. The results of the direct analysis from exogenous variables to endogenous variable, found that the academic aspect has a positive and significant influence on student satisfaction with $\mathrm{t}$-value $=$ 2.43; Non academic aspect has a positive and significant influence on student satisfaction with t-value $=2.64$; Access has a positive and significant influence on student satisfaction with t-value $=2.19$; Program Issue has a positive and significant influence on student satisfaction with t-value $=2.03$; Reputation has no influence on student satisfaction with $\mathrm{t}-\mathrm{value}=(-1.01)$; Motivation has a positive and significant influence on student satisfaction with $\mathrm{t}$-value $=3.83$. After conducting the first analysis, which tested the direct influence of each exogenous variable on the endogenous ones, the results were interacted to produce hypothesis analysis, using motivation as a moderating variable with LISREL output, as follows:

Hypothesis testing is done with a significance level of 5\%, resulting in a critical tvalue of \pm 1.96 . The hypothesis is accepted if the $t$-value obtained is $\geq 1.96$, while the hypothesis is not supported if $\mathrm{t}$-value obtained is $<1.96$. The following Table 5 of hypothesis testing answes all research questions:

Figure 2. Structural Model-Moderating (Standardized Solution)

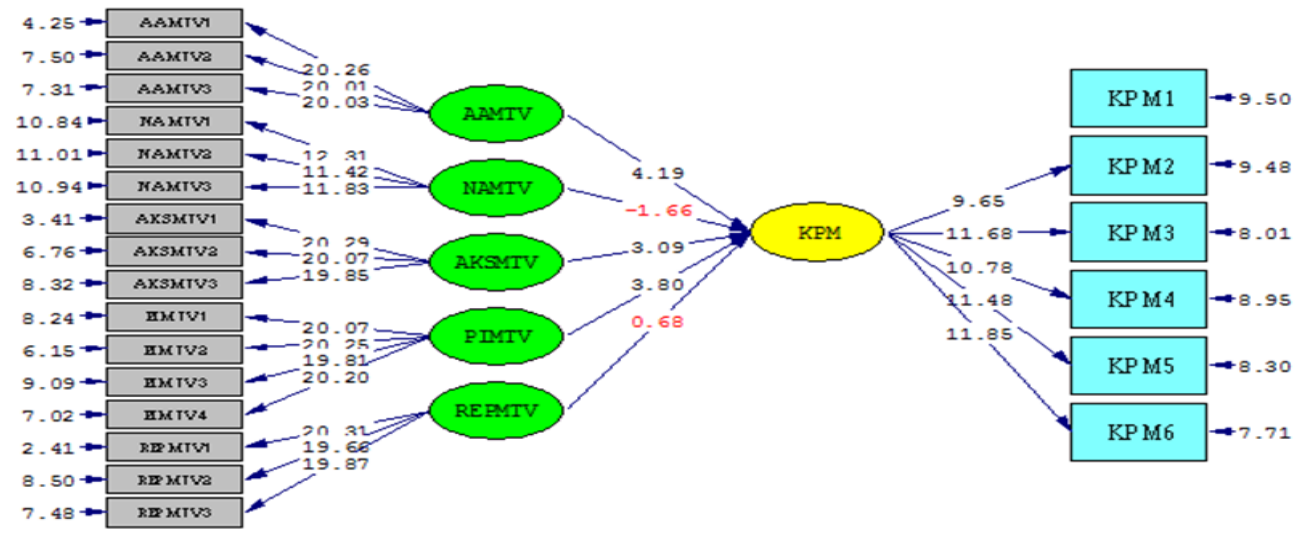

Source: Output LISREL 8.80 
Table 5. Hypothesis Research Model Test Result

\begin{tabular}{|c|c|c|c|c|c|}
\hline $\begin{array}{l}\text { Hypot } \\
\text { heses }\end{array}$ & Statement & $\begin{array}{l}\text { T- } \\
\text { Value }\end{array}$ & $\begin{array}{l}\text { T- } \\
\text { Table }\end{array}$ & $\begin{array}{l}\text { Loadi } \\
\text { ng } \\
\text { Factor }\end{array}$ & Explanation \\
\hline $\mathbf{H}_{1}$ & $\begin{array}{l}\text { The academic aspect has a positive and significant } \\
\text { influence on student satisfaction moderated by } \\
\text { motivation. }\end{array}$ & 4.19 & 1.96 & 0.37 & Significant \\
\hline $\mathbf{H}_{2}$ & $\begin{array}{l}\text { The non-academic aspect has a positive and } \\
\text { significant effect on student satisfaction moderated } \\
\text { by motivation. }\end{array}$ & -1.66 & 1.96 & -0.13 & $\begin{array}{l}\text { Not } \\
\text { Significant }\end{array}$ \\
\hline $\mathbf{H}_{3}$ & $\begin{array}{l}\text { Access has a positive and significant influence on } \\
\text { student satisfaction moderated by motivation. }\end{array}$ & 3.09 & 1.96 & 0.22 & Significant \\
\hline $\mathbf{H}_{4}$ & $\begin{array}{l}\text { Program Issues have a positive and significant } \\
\text { influence on student satisfaction moderated by } \\
\text { motivation. }\end{array}$ & 3.8 & 1.96 & 0,42 & Significant \\
\hline $\mathbf{H}_{5}$ & $\begin{array}{l}\text { Reputation has a positive and significant influence on } \\
\text { student satisfaction moderated by motivation. }\end{array}$ & 0.6 & 1.96 & 0.07 & $\begin{array}{l}\text { Not } \\
\text { Significant }\end{array}$ \\
\hline
\end{tabular}

Source: Analysis output (2017).

Based on the results of data processing from the structural model, the authors obtained the output results in the form of t-value. Hypothesis 2 and 5 obtained a tvalue which was <1.96, which means that there is no significant moderation influence of the motivation variable to non-Academic aspects and reputation to student satisfaction. However, motivation moderates significantly the positive influence of academic aspect, access and program issues on student satisfaction, where the t-value on the hypothesis path is greater than the critical value of 1.96 .

\subsection{Dimension Analysis}

To analyse the strength of the relation dimension of exogenous variables with dimensions of endogenous variables, the authors used matrix correlation dimension between variable. Below is the dimension correlation matrix between dimensions:

Table 6. Matrix Correlation Dimension Between Variable

\begin{tabular}{|c|c|c|c|c|c|c|}
\hline \multirow[b]{2}{*}{ Variabel } & \multirow[b]{2}{*}{ Dimensi } & \multicolumn{2}{|c|}{ Motivasi } & \multicolumn{3}{|c|}{ Kepuasan Mahasiswa } \\
\hline & & $\begin{array}{l}\text { y1 } \\
\text { Intrinsi } \\
\mathrm{c}\end{array}$ & $\begin{array}{l}\text { y2 } \\
\text { Extrinsi } \\
\mathrm{c}\end{array}$ & $\begin{array}{l}\text { z1 } \\
\text { Custome } \\
\text { r Service } \\
\text { Model }\end{array}$ & $\begin{array}{l}\text { z2 } \\
\text { Happy } \\
\text { Productiv } \\
\text { e Model }\end{array}$ & $\begin{array}{l}\text { z3 } \\
\text { The } \\
\text { Invest } \\
\text { ment } \\
\text { Model }\end{array}$ \\
\hline Motivation & y1 (Intrinsic) & 1 & 1 & 0.391 & 0.454 & 0.459 \\
\hline (y) & y2 (Extrinsic) & 1 & 1 & 0.310 & 0.414 & 0.393 \\
\hline HEdPERF & Academic Aspect (x1) & 0.296 & 0.282 & 0.553 & 0.580 & 0.595 \\
\hline Model & $\begin{array}{l}\text { Non-Academic Aspect } \\
(\mathrm{x} 2)\end{array}$ & 0.249 & 0.267 & 0.502 & 0.495 & 0.530 \\
\hline & Access (x3) & 0.309 & 0.323 & 0.470 & 0.523 & 0.530 \\
\hline & Program Issues (x4) & 0.451 & 0.311 & 0.564 & 0.598 & 0.632 \\
\hline & Reputation (x5) & 0.392 & 0.378 & 0.455 & 0.516 & 0.552 \\
\hline
\end{tabular}




\section{Discussion and Conclusion}

1. Non-traditional students have unique conditions, whereby they already have experience in work, and they have different needs and expectations from traditional students. Time is what they think is valuable. In terms of perceptions of lecturers, non-traditional students who may be older than the lecturers who teach lessons, tend to be dissatisfied with the degree and qualifications of the lecturers, but expect the development of skills and talents, and the acquisition of knowledge, which will help them to getting their degree. Some of these nontraditional students went through undergraduate programs in the past years. The academic aspect has a significant effect on student satisfaction through motivation as a moderator with t-value of 4.19. And intrinsic motivation is the dominant dimension in influencing perception of service quality to satisfaction. That is, the greater the intrinsic motivation of non-traditional students to return to college, the stronger their level of satisfaction will be. Based on the calculation of the correlation between variable dimensions, this academic aspect has a dominant relationship with the investment model. That is, the satisfaction is felt when students feel that the academic aspect is relative to the time and expenses they spend for college.

2. Motivation does not moderate non-academic aspects of student satisfaction with $\mathrm{t}$-value of -1.66 . However, the non-academic aspect directly affects positively and significantly student satisfaction with t-value of 2.64. According to the results of the correlation analysis of dimensions between variables, this nonacademic aspect has a strong relationship with the Investment Model, meaning the administrative process and the behavior reflected by the administrative staff towards the students affects the reaction of students in relation to time and effort in college.

3. Access has a significant effect on student satisfaction through motivation as moderator with $\mathrm{t}$-value of 3.09. Based on the calculation of the dimension correlation between variables, this access has a dominant relationship with the investment model. The satisfaction they feel in response to the perception of access is influenced by extrinsic motivation, meaning that the greater the extrinsic motivation of non-traditional students to return to college, of the stronger the satisfaction. However, this access also has a significant direct effect on student satisfaction. In this case, motivation as moderation variable acts as quasi moderation, meaning that it can moderate between the academic aspect and student satisfaction variables but can also act as a predictor or exogenous variable.

4. Program Issues significantly influence student satisfaction through motivation as moderator with t-value of 3.80. Based on the calculation of dimension correlation between variables, this issue program has a dominant relationship with the investment model, meaning that students will relate their perception of program issues at UMB with the cost and time they spend on studying. The amount of the satisfaction they feel in response to the perception of program issues is influenced by intrinsic motivation, meaning that the greater the intrinsic 
motivation of non-traditional students to return to college, the greater the satisfaction with program issues. However, the issue of this program also has a significant direct effect on student satisfaction. In this case, motivation as a moderating variable, acts as quasi moderation, which means it can moderate between the academic aspect and student satisfaction variables, but can also act as a predictor or exogenous variable.

5. Reputation has no positive and significant effect on student satisfaction, either directly or through motivation as motivation variable.

In accordance with the results of inter-dimensional correlations, program issues have a dominant correlation over other dimension variables. This means that if the University focuses more on improving and upgrading program issues, including program quality, width of program range, experience in teaching, and time flexibility, other aspects of academic, non-academic access and reputation aspects, this will increase student satisfaction. The University may pay attention to program issues on:

a. Program quality. Perceptions about the quality of teaching programs are gained when students feel it takes hard work to get good grades and to graduate. The idea that students are meant to achieve a certain standard of assessment suggests a quality in the mind of the student, especially if the outcome of the lecture can effectively be applied in the workplace. Hence, the University needs to consider the quality of its programs over the quantity, to achieve a better image.

b. Variability of program specialization. The postgraduate program of UMB offers 6 (six) courses, and Master of Management has 4 (four) concentrations up to the academic year 2016/2017. The variety of programs needs to be considered by the University, to see if it is possible to add some more program specializations, yet maintaining a high standard, i.e. by ensuring competent faculties in the field.

c. Delivery of teaching. UMB's experience in teaching since 1985 is a University asset, that can improve its professional image. This perception has a significant loading factor of 0.64 . Thus, the University can accentuate this to advertise the University, and pay attention to this so that the image of a good experience continues to be inherent in society.

d. Flexibility of structure and time. The number of students in the weekend classes increased dramatically from year to year, reaching $50 \%$ of the total number of students (source: UMB directorate of student affair), and these classes are increasingly in demand by non-traditional students who have limited time in the middle of the week. The University needs to constantly adjust to the rules set by the government in the course operations. Nevertheless, it continually strives to improve students' capabilities, both in terms of time and structure.

\section{References:}

Abdullah, F. 2005. HEdPERF versus SERVPERF. Quality Assurance in Education, Vol. 13, Iss. 4, pp. 305-328.

Abdullah, F. 2006. Measuring Service Quality in Higher Education. HEdPERF versus 
SERVPERF. Marketing Intelligence \& Planning, 24(1), 31-47.

Abdullah, F. 2006a. The development of HEdPERF: a new measuring instrument of quality for the higher education sector. International Journal of Consumer Studies, 569-581.

Ali, F., Zhou, Y., Hussain, K., Nair, P.K. \& Ragavan, N.A. 2016. Does higher education service quality effect student satisfaction, image and loyalty? Quality Assurance in Education, Vol. 24, Iss. 1, pp. 70-94.

Azoury, N., Daou, L., Khoury, C.E.L. 2014. University image and its relationship to student satisfaction- case of the Middle Eastern private business schools. International Strategic Management Review, Vo. 2, No. 1, 1-8.

Brown, R., Mazzarol, T. 2009. The importance of institutional image to student satisfaction and loyalty within higher education. Higher education, Vol. 55, No.1, pp.17-31.

Carter, P. 2014. A case study of student satisfaction. Kyushu Sangyo University.

Elliot, K. \& Shin, D. 2002. Student satisfaction: An alternative approach to assessing this important concept. Journal of Higher Education Policy and Management, 24(2), 197-209.

Galbraith, M.W. 1990. Attributes and skills of an adult educator. In M.W. Galbraith (Ed.). Adult learning methods (pp. 3-22). Malabar, FL: Krieger Publishing Company.

Gibson, A. 2010. Measuring business student satisfaction: A review and summary of the major predictors. Journal of Higher Education Policy and Management, 32(3), 251259.

Hair, J.F., Hult, G.M.T., Ringle, C.M, \& Sarstedt, M. 2014. A Primer on Partial Least Squares Structural Equation Modeling (PLS-SEM). Sage: Thous \& Oaks.

Hill, F.M. 1995. Managing service quality in higher education: The role of the student as primary consumer. Quality Assurance in Education, 10.

Horn, L.J. 1996. Nontraditional undergraduates: Trends in enrollment from 1986 to 1992 and persistence and attainment among 1989-90 beginning postsecondary students (NCES 97-578). U.S. Department of Education, NCES. Washington, DC: U.S. Government Printing Office.

Jalasi, Azrin, B. 2014. Measuring Service Quality in Malaysian Polytechnic: Applying HEdPERF Model as New Measurement Scales for Higher Education Sector. Business Research Colloquium, 1-12.

Orîndaru, A. 2015. Changing Perspectives on Students in Higher Education. Procedia Economics and Finance, 27, 682-691.

Ryan, M.R., Deci, E.L. 2000. Intrinsic and Extrinsic Motivation: Classic Definitions and New Directions. Contemporary Educational Psychology, 25, 54-67.

Subrahmanyam, Annamdevula, A., Raja, Shekhar, B. 2012. Development of HEdQUAL for Measuring Service Quality in Indian Higher Education Sector. International Journal of Innovation, Management and technology, 3(4), 412-416.

Vidaver-Cohen, D. 2007. Reputation beyond the rankings: A conceptual framework for business school research. Corporate Reputation Review, 10(4), 278-304.

Wu, H., Tennyson, R.D. \& Hsia, T. 2010. A Study of Student Satisfaction in a Blended ELearning System Environment. Computer and Education, 55, 155-164. 